Het gezin centraal 



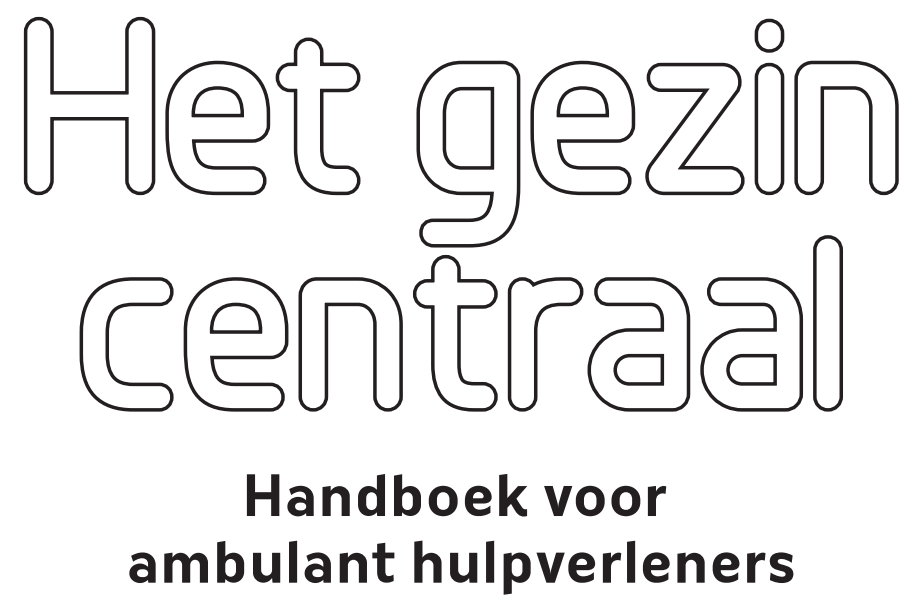

Arjan Bolt 
Eerste tot en met achtste druk, 2006-2015 (ISBN 978906665655 0)

Negende compleet herziene druk, 2017

\section{Het gezin centraal}

Handboek voor ambulant hulpverleners

Arjan Bolt

ISBN 9789088506598

NUR 847

(C) 2017 B.V. Uitgeverij SWP Amsterdam

Alle rechten voorbehouden. Niets uit deze uitgave mag worden verveelvoudigd, opgeslagen in een geautomatiseerd gegevensbestand, of openbaar gemaakt, in enige vorm of op enige wijze, hetzij elektronisch, mechanisch, door fotokopieën, opnamen, of enige andere manier, zonder voorafgaande schriftelijke toestemming van de uitgever.

Voor zover het maken van kopieën uit deze uitgave is toegestaan op grond van artikel 16B Auteurswet $1912 \mathrm{j}^{\circ}$ het Besluit van 20 juni 1974, St.b. 351, zoals gewijzigd bij het besluit van 23 augustus 1985, St.b. 471 en artikel 17 Auteurswet 1912, dient men de daarvoor wettelijk verschuldigde vergoedingen te voldoen aan de Stichting Reprorecht (Postbus 3060, $2130 \mathrm{~KB}$ Hoofddorp). Voor het overnemen van gedeelte(n) uit deze uitgave in bloemlezingen, readers en andere compilatiewerken (artikel 16 Auteurswet 1912) dient men zich tot Uitgeverij SWP (Postbus 12010, 1100 AA Amsterdam-Zuidoost) te wenden. 
Wat wij in het leven het meest nodig hebben, is iemand die ons ertoe brengt te doen waartoe wij in staat zijn.

Ralph Waldo Emerson (Amerikaans dichter en schrijver, 1803-1882) 
Dit boek draag ik op aan mijn broer Hielko (1966-2011) 


\section{Voorwoord bij de herziene druk}

Steve de Shazer, een van de grondleggers van de oplossingsgerichte benadering, en een grote inspiratiebron voor mij heeft eens gezegd, om uit te leggen waar het om gaat in de oplossingsgerichte therapie: 'To me ... the danger of reading between the lines is that there might be nothing there. So you've just got to listen to what the client says.'

Recentelijk heb ik meneer en mevrouw S. mogen interviewen. Zij zijn de ouders van een samengesteld gezin met vijf kinderen dat met een opeenstapeling van problemen en zorgen kampt. Het gezin kreeg van hun hulpverleners de kwalificatie multiprobleemgezin. In de contacten met hulp- en dienstverleners hebben ze nogal wat schrammen en builen opgelopen. Maar ze hebben ook positieve ervaringen opgedaan. Ik heb ze gevraagd of ze ons, professionals in de jeugdsector, een advies willen geven. En het advies komt hierop neer: 'Luister goed naar ons. Druk niet je eigen mening door, maar luister en neem onze wensen en onze intenties serieus.' En zo eenvoudig kan de clou van goede hulpverlening verwoord worden. De kans is niet groot dat de familie S. ooit van Steve de Shazer gehoord heeft, laat staan andersom, maar als dat wel het geval is, zouden ze het hardgrondig met elkaar eens zijn.

Het is belangrijk niet te licht over 'goed luisteren' te denken. Er valt veel over te zeggen. Dit beweer ik niet om de dikte van het boek dat voor je ligt te verantwoorden. Vooruit, misschien een beetje dan.

Goed en zorgvuldig luisteren naar en doorvragen op de verhalen van gezinsleden over hun leven en beleven, vraagt een hoge mate van professionaliteit. Het vraagt de methodische vaardigheden die in Het gezin centraal aan bod komen, maar ook inlevingsvermogen en oprechte nieuwsgierigheid. We moeten niet te snel denken dat we wel begrijpen wat 'ze' bedoelen. Daar doelt Steve de Shazer op als hij het over 'het gevaar' van het lezen tussen de regels door heeft. Het vermogen om soms 'niet te weten' vormt een cruciaal onderdeel van je professie. Zo ben je in staat je te verdiepen in de perceptie van de ander, zie je het perspectief van degene met wie je spreekt. Het gaat erom dat je weet wanneer je welke vragen moet stellen, om vervolgens zorgvuldig te luisteren voordat je besluit welke vervolgvraag passend is en bijdraagt aan een positieve uitkomst van de hulp.

Daarmee kan de samenvatting van Het gezin centraal, dankzij Steve de Shazer én de heer en mevrouw S., kort en kernachtig zijn: Luister zo goed als je kunt en wees wezenlijk geinteresseerd in wat de cliënt te zeggen heeft!

De inhoud van deze gewijzigde druk is tot stand gekomen in nauwe samenwerking met mijn collega's Renske van Bemmel en Ella Tacq. Het gezin centraal verwoordt onze gemeenschappelijke visie op en ons gezamenlijke gedachtegoed met betrekking tot jeugd- en gezinshulpverlening. Die proberen we telkens in onze houding, spreken en handelen uit te dragen als we via trainingen, workshops, (team)coaching of andere gelegenheden in aanraking komen 
met jeugd- en gezinshulpverleners in de verschillende rollen en functies die er zijn in de jeugdsector.

In 2015 is het kenniscentrum Gezin Centraal opgericht (www.gezincentraal.nl). Doel van het kenniscentrum is het genereren en delen van kennis en het inspireren van collega's. In het kenniscentrum werken we nauw samen met professionals, instellingen en Praktikon, een organisatie voor onderzoek en ontwikkeling, onder andere in de jeugdsector. Kennisdeling en monitoren van kwaliteit zijn belangrijke vernieuwende ontwikkelingen rond Gezin Centraal en hebben bijgedragen aan de totstandkoming van een update van Het gezin centraal. Onze missie is een substantiële bijdrage leveren aan de aantoonbare werkzaamheid van gezinsgerichte hulp in de jeugdsector.

De werkzaamheid van jeugd- en gezinshulpverlening wordt naar onze mening grotendeels bepaald door de persoon van de professional. Elke methode is tenslotte zo goed als de uitvoerder. Reden waarom ik me bij het schrijven heb laten inspireren door de verhalen uit de praktijk van jeugd- en gezinshulpverleners. Blijf je als gezinshulpverlener ontwikkelen door zorgvuldig te luisteren naar wat je cliënten en je collega's over je te melden hebben. Ook dan is het relevant niet te proberen tussen de regels door te willen lezen, maar je niet-wetenhouding te handhaven en de feedback te nemen voor wat het is. Dan profiteer je er het meeste van.

Het gezin centraal is niet geschreven om je te vertellen hoe je een goede gezinshulpverlener kunt worden. Het boek is primair bedoeld om jou en vele andere hardwerkende en bekwame professionals in dit mooie en soms moeilijke vak - en degenen die nog in opleiding zijn - te inspireren en aan te moedigen het verschil te willen blijven maken voor jeugd en gezinnen in nood. Dus: keep up the good work!

Arjan Bolt 


\section{Inhoud}

1 Gezinshulpverlening: doelgroep, doelen en varianten $\quad 25$

$\begin{array}{lll}1.1 & \text { Inleiding } & 25\end{array}$

1.2 Doelgroep: de gezinnen en hun vragen $\quad 27$

1.2.1 Wat is een gezin? $\quad 27$

1.2.2 Opgroei- en opvoedproblemen 29

1.2.3 Risicofactoren en beschermende factoren 30

1.2.4 Kindkenmerken $\quad 32$

1.2.5 Ouderkenmerken $\quad 34$

$\begin{array}{ll}\text { 1.2.6 Gezinskenmerken } & 37\end{array}$

1.2.7 Omgevingskenmerken $\quad 41$

1.2.8 Van licht probleem tot multiprobleem 43

1.2.9 Hulpvragen 44

1.3 Doelen van gezinshulpverlening: gedragsverandering en empowerment 45

1.4 Enkelvoudige ambulante gezinshulpverlening 46

1.5 Meervoudige jeugd- en gezinshulp: werken volgens 1Gezin1Plan 48

1.6 Gezinshulpverlening bij jeugdhulp met verblijf 52

1.6.1 Gezinshulpverlening bij de verschillende verblijfsvoorzieningen $\quad 52$

1.6.2 Een omslag in denken over jeugdhulp met verblijf 54

1.6.3 De werkwijze: gezinsgecentreerde jeugdhulp met verblijf 54

1.6.4 De gezinshulpverlener als trajectbegeleider 56

$\begin{array}{lll}\text { 1.6.5 Werken naar perspectief } & 57\end{array}$

1.6.6 Het gezin centraal bij verblijf als beleid $\quad 60$

$\begin{array}{lll}1.7 & \text { De jeugdgeneralist in de wijk } & 60\end{array}$

2 Basisattitude en werkzaamheid $\quad 65$

2.1 Twee pijlers: vraaggerichtheid en gezinsgerichtheid 65

$\begin{array}{lll}2.2 & \text { Vraaggerichtheid en participatie } & 67\end{array}$

$\begin{array}{lll}2.3 & \text { Kenmerken van vraaggericht werken } & 69\end{array}$

$\begin{array}{lll}2.4 & \text { Gezinsgerichtheid } & 74\end{array}$

2.5 Assumpties: tien uitgangspunten $\quad 76$

2.6 Werkzaamheid, effectiviteit en kwaliteitsmeting 77

2.6.1 Algemeen en specifiek werkzame factoren $\quad 77$

2.6.2 Evidence-based interventies $\quad 80$

2.6.3 Knelpunten van effectmeting bij erkende programma's 80

2.6.4 Van programma's naar werkzame elementen 84

2.6.5 Elke methode is zo goed als haar uitvoerders: de factor van de hulpverlener 85 
2.7 Gezin Centraal en de werkzame bestanddelen van gezinshulpverlening $\quad 88$

2.7.1 Factoren en elementen $\quad 88$

2.7.2 De werkzaamheid van vraaggericht en gezinsgericht werken $\quad 89$

2.7.3 Werkzame kernelementen van Gezin Centraal 92

2.7.4 De werkzaamheid van systematische reflectie 95

3 De theorie $\quad 97$

$\begin{array}{lll}3.1 & \text { Inleiding } & 97\end{array}$

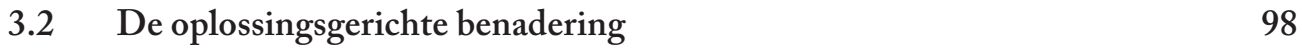

3.2.1 Paradigmaverschuiving 98

3.2.2 Welk alternatief biedt de oplossingsgerichte benadering? 98

3.2.3 Het construeren van oplossingen $\quad 99$

$\begin{array}{lll}\text { 3.2.4 De achtstappendans } & 100\end{array}$

3.3 De systeembenadering en de contextuele benadering 104

$\begin{array}{ll}\text { 3.3.1 Systeembenadering } & 104\end{array}$

$\begin{array}{ll}\text { 3.3.2 Gezinstherapeutische benadering } & 107\end{array}$

$\begin{array}{ll}\text { 3.3.3 Gezinstherapie en de oplossingsgerichte benadering } & 108\end{array}$

$\begin{array}{ll}\text { 3.3.4 De gezinshulpverlener als systeemgerichte hulpverlener } & 109\end{array}$

$\begin{array}{ll}\text { 3.3.5 Contextuele benadering } & 109\end{array}$

3.3.6 Een voorbeeld van systeemgericht en contextueel werken 111

$\begin{array}{lll}3.4 & \text { Leertheorie } & 112\end{array}$

$\begin{array}{lll}3.4 .1 & \text { Vier varianten } & 112\end{array}$

$\begin{array}{lll}3.4 .2 & \text { Klassieke leertheorie } & 112\end{array}$

$\begin{array}{ll}\text { 3.4.3 Operante leertheorie } & 113\end{array}$

$\begin{array}{ll}3.4 .4 \text { Sociale leertheorie } & 115\end{array}$

$\begin{array}{ll}\text { 3.4.5 Zelfregulering } & 116\end{array}$

$\begin{array}{lll}3.5 & \text { Competentiegerichte hulpverlening } & 117\end{array}$

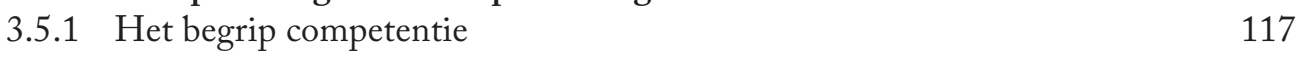

$\begin{array}{lll}\text { 3.5.2 Ontwikkelingstaken } & 118\end{array}$

$\begin{array}{ll}\text { 3.5.3 Competentievergroting en empowerment } & 123\end{array}$

$\begin{array}{lll}3.6 & \text { Communicatietheorie } & 124\end{array}$

$\begin{array}{ll}\text { 3.6.1 Het begrip communicatie } & 124\end{array}$

$\begin{array}{ll}\text { 3.6.2 Basiscommunicatie en videohometraining } & 126\end{array}$

$\begin{array}{ll}\text { 3.6.3 Communicatieregels } & 126\end{array}$

3.6.4 De communicatieregels en oplossingsgericht werken 129

4 De fasering en de cliëntcontacten 131

$\begin{array}{lll}4.1 & \text { Inleiding } & 131\end{array}$

4.2 Aanmeldfase $\quad 133$

$\begin{array}{lll}\text { 4.2.1 De eerste contacten } & 133\end{array}$

$\begin{array}{ll}\text { 4.2.2 Starten met het hele gezin } & 134\end{array}$

$\begin{array}{ll}\text { 4.2.3 Kennismakingsgesprek } & 135\end{array}$

$\begin{array}{ll}\text { 4.2.4 Afstemmingsgesprek } & 137\end{array}$

$\begin{array}{ll}\text { 4.2.5 Kennismaking en afstemming in schema } & 140\end{array}$ 
$\begin{array}{lll}4.3 & \text { Inventarisatiefase } & 142\end{array}$

$\begin{array}{lll}\text { 4.3.1 Inventariseren } & 142\end{array}$

4.3.2 Het gezinsplan en het eerste voortgangsgesprek 143

4.3.3 Het raamgezinsplan in het kader van 1Gezin1Plan 144

$\begin{array}{lll}\text { 4.3.4 Beslissen over hulp } & 146\end{array}$

$\begin{array}{lll}\text { 4.3.5 Rondetafeloverleg } & 148\end{array}$

4.3.6 Besluitvorming met het sociale netwerk 149

$\begin{array}{lll}4.4 & \text { Veranderingsfase } & 151\end{array}$

4.4.1 Werken aan doelen 151

$\begin{array}{lll}\text { 4.4.2 Soorten cliëntcontacten } & 154\end{array}$

4.4.3 Structuur van een hulpverleningsgesprek 155

$\begin{array}{lll}\text { 4.4.4 Evalueren van de voortgang } & 159\end{array}$

4.4.5 Evalueren in een rondetafeloverleg 161

$\begin{array}{lll}\text { 4.4.6 Driehoeksgesprek } & 162\end{array}$

$\begin{array}{lll}4.5 & \text { Afbouwfase } & 164\end{array}$

4.6 Fasering van gezinsgecentreerde jeugdhulp met verblijf 166

$\begin{array}{lll}4.7 & \text { Cyclus van de gezinshulpverlening } & 168\end{array}$

$\begin{array}{lll}4.8 & \text { De structuur van doelen } & 170\end{array}$

5 Basisvaardigheden: samenwerken en niet-weten 173

$\begin{array}{lll}5.1 & \text { Inleiding } & 173\end{array}$

5.2 Werken met verschillende samenwerkingsrelaties $\quad 174$

$\begin{array}{ll}\text { 5.2.1 Aandacht voor de relatie } & 174\end{array}$

$\begin{array}{lll}\text { 5.2.2 Stroomschema } & 175\end{array}$

$\begin{array}{lll}\text { 5.2.3 Probleem of beperking } & 177\end{array}$

$\begin{array}{lll}\text { 5.2.4 De vrijblijvende relatie } & 179\end{array}$

$\begin{array}{lll}\text { 5.2.5 De zoekende relatie } & 181\end{array}$

$\begin{array}{lll}\text { 5.2.6 De consulterende relatie } & 183\end{array}$

$\begin{array}{lll}\text { 5.2.7 De co-expertrelatie } & 184\end{array}$

$\begin{array}{ll}\text { 5.2.8 Samenwerkingsrelaties in gezinnen } & 185\end{array}$

$\begin{array}{lll}\text { 5.2.9 } & \text { Samenwerkingsrelaties en aanpak in schema } & 186\end{array}$

$\begin{array}{lll}5.3 & \text { Niet-weten en de samenwerkingsrelatie } & 188\end{array}$

$\begin{array}{lll}\text { 5.3.1 'Niet-weten' als professie } & 188\end{array}$

$\begin{array}{lll}\text { 5.3.2 Invoegen } & 189\end{array}$

$\begin{array}{lll}\text { 5.3.3 Actief luisteren } & 191\end{array}$

$\begin{array}{lll}\text { 5.3.4 Feedback en de werkrelatie } & 195\end{array}$

$\begin{array}{lll}\text { 5.3.5 Bieden van emotionele steun } & 200\end{array}$

$\begin{array}{lll}\text { 5.3.6 Informeren } & 202\end{array}$

$\begin{array}{lll}5.4 & \text { Niet-weten bij gezinsgesprekken } & 203\end{array}$

5.4.1 Taxeren in rondes 203

$\begin{array}{lll}\text { 5.4.2 Beurt verdelen en structureren van een gezinsgesprek } & 204\end{array}$

5.4.3 Circulaire vragen stellen 205

$\begin{array}{lll}\text { 5.4.4 Positief etiketteren } & 207\end{array}$

5.4.5 Interactioneel herformuleren 208 
$\begin{array}{lll}5.5 & \text { Netwerkgerichte gespreksvoering } & 209\end{array}$

5.6 Interculturele competentie en culturele sensitiviteit 211

5.6.1 Niet-weten en intercultureel werken 211

$\begin{array}{ll}\text { 5.6.2 Ik-cultuur en wij-cultuur } & 211\end{array}$

5.6.3 Interculturele competentie 213

$\begin{array}{ll}\text { 5.6.4 Voorwaarden } & 214\end{array}$

$\begin{array}{ll}\text { 5.6.5 Culturele sensitiviteit } & 215\end{array}$

$\begin{array}{ll}\text { 5.6.6 Communicatievaardigheden } & 217\end{array}$

5.7 De basisvaardigheden nog eens op een rij 223

6 Technieken voor het verzamelen van informatie 225

$\begin{array}{lll}6.1 & \text { Inleiding } & 225\end{array}$

6.2 De basistechnieken: observeren en luisteren 226

6.2.1 Observeren: waarnemen of doorvragen 226

$\begin{array}{ll}\text { 6.2.2 Observeren uit eerste hand } & 227\end{array}$

6.2.3 Zelfobservatie met behulp van videobeelden 228

6.2.4 Inzoomen door vragen te stellen 229

6.2.5 Observeren uit tweede hand 231

6.3 Inventariseren van de klachten en de hulpvraag 231

6.3.1 Probleemdefiniëring en hulpvraagverkenning 231

6.3.2 Hulpvraagverkenning met behulp van inzoomen (casus Van Kooten I) 233

6.4 Vaststellen van het einddoel 234

6.4.1 Toekomstprojecties en doelformuleringsvragen 234

6.4.2 De wondervraag 235

$\begin{array}{ll}\text { 6.4.3 De wondervraag in gezinsgesprekken } & 237\end{array}$

6.4.4 Inzoomen op het wonder (casus Van Kooten II) 239

6.4.5 Omgaan met lastige of ontwijkende antwoorden op de wondervraag 240

6.5 Stellen van werkdoelen $\quad 241$

$\begin{array}{lll}\text { 6.5.1 Doelen } & 241\end{array}$

$\begin{array}{lll}\text { 6.5.2 Exploreren van uitzonderingen } & 244\end{array}$

6.5.3 Copingvragen 246

$\begin{array}{ll}\text { 6.5.4 Schaalvragen } & 247\end{array}$

6.5.5 Observatie- en registratieopdrachten 248

6.5.6 Inzoomen op de uitzondering (casus Van Kooten III) 250

6.6 Competentieanalyse 252

6.7 Vragenlijst Dagelijkse Routine 255

6.8 Analyse van het sociale netwerk 256

6.8.1 Hulpmiddelen bij netwerkgerichte gespreksvoering 256

$\begin{array}{ll}\text { 6.8.2 Het vierkolommenmodel } & 257\end{array}$

6.8.3 Het genogram 258

6.8.4 Het sociogram en de netwerklijst $\quad 262$

$\begin{array}{lll}\text { 6.8.5 De levenslijn } & 264\end{array}$

$\begin{array}{lll}\text { 6.9 Beeldtaal } & 264\end{array}$

6.10 Evalueren en bijstellen van doelen 266

$\begin{array}{lll}6.11 & \text { Bijlagen } & 270\end{array}$ 
7.2 Gedragsverandering: kleine stappen naar grote doelen 277

$\begin{array}{lll}\text { 7.2.1 Concrete Aanzet tot Beweging (CAB) } & 277\end{array}$

7.2.2 Werken an doelen met werkplannen $\quad 279$

7.2.3 Volgen van het tempo van de cliënt (casus Van Kooten IV) 281

$\begin{array}{lll}7.3 & \text { Ontdekken en benutten van krachten en vaardigheden } & 287\end{array}$

$\begin{array}{lll}\text { 7.3.1 Informatie verzamelen } & 287\end{array}$

$\begin{array}{lll}\text { 7.3.2 Inzoomen op positieve uitzonderingen } & 287\end{array}$

7.3.3 Abstraheren van vaardigheden (casus Van Kooten V) 288

$\begin{array}{lll}\text { 7.3.4 De uitzondering recht onder je neus } & 292\end{array}$

7.3.5 Bespreken van de dagelijkse routine van het gezin 294

7.4 Versterken en uitbreiden van krachten en vaardigheden 296

7.4.1 Oefenen 296

$\begin{array}{lll}\text { 7.4.2 De individuele vaardigheidsoefening } & 297\end{array}$

7.4.3 De oefening met het gezin of met meerdere gezinsleden 301

7.4.4 Oefenen van gezinsinteracties met behulp van videobeelden (casus Van Kooten VI) 305

$\begin{array}{lll}7.5 & \text { De methode van de drie gebeurtenissen } & 307\end{array}$

7.6 Gezinsgesprek rond een specifiek probleem of specifieke situatie $\quad 319$

$\begin{array}{lll}7.7 & \text { Adviezen en instructies } & 327\end{array}$

7.8 Werken aan vaardigheden voor het omgaan met cognities en emoties 331

7.8.1 De vijf G's: oefening storende en helpende gedachten 331

$\begin{array}{lll}\text { 7.8.2 De gevoelsthermometer en de eerstehulpkaart } & 338\end{array}$

$\begin{array}{lll}\text { 7.8.3 De stemmingsmeter } & 340\end{array}$

$\begin{array}{lll}\text { 7.8.4 Het A-B-A-gesprek } & 341\end{array}$

7.8.5 Communiceren op schrift of per telefoon 342

7.9 Werken aan samenwerking van ouders, opvoeders en ex-partners 342

$\begin{array}{lll}\text { 7.9.1 Opvoeden en samenwerken } & 342\end{array}$

$\begin{array}{lll}\text { 7.9.2 Werken an gezamenlijke doelen } & 343\end{array}$

7.9.3 Gezinshulpverlening bij scheiding 346

$\begin{array}{lll}\text { 7.9.4 De stem van het kind en loyaliteit } & 348\end{array}$

$\begin{array}{ll}\text { 7.9.5 Bemiddeling en kennis } & 350\end{array}$

7.9.6 Werken an vertrouwen 352

7.9.7 Omgaan met ruzie en strijd tijdens het gesprek 353

$\begin{array}{lll}\text { 7.9.8 Samengestelde gezinnen } & 354\end{array}$

$\begin{array}{lll}7.10 & \text { Bijlagen } & 357\end{array}$

8 Opvoeding, ouderschap en opvoedingsvaardigheden 359

$\begin{array}{lll}8.1 \quad \text { Inleiding } & 359\end{array}$

8.2 Opvoeding en het gewone leven 360

$\begin{array}{lll}\text { 8.2.1 Een eeuwigdurend debat } & 360\end{array}$

8.2.2 Wat is opvoeden eigenlijk? 364

8.2.3 Goed (genoeg) ouderschap? 366

8.2.4 Herstel van het gewone opvoeden 374 
8.3.1 Vier categorieën $\quad 375$

8.3.2 Overkoepelende opvoedingsvaardigheden en -strategieën 377

8.3.3 Stimuleren en aanleren van gedrag (vaardigheden voorafgaand aan het gedrag)

8.3.4 Versterken van gewenst gedrag (vaardigheden volgend op het gedrag) 383

8.3.5 Afzwakken en stoppen van gedrag (vaardigheden volgend op het gedrag) 387

8.3.6 Opvoeden van pubers en adolescenten en met hen communiceren 395

8.4 Versterken en oefenen van opvoedingsvaardigheden 401

$\begin{array}{ll}\text { 8.4.1 Informeren over opvoeden } & 401\end{array}$

8.4.2 Oefenen 402

8.4.3 Een zich regelmatig herhalende gebeurtenis (casus Van Kooten VII) 403

$\begin{array}{ll}\text { 8.5 Aandacht voor veilige gehechtheid } & 411\end{array}$

8.5.1 Ontwikkeling van veilige gehechtheid 411

$\begin{array}{ll}\text { 8.5.2 Problematische gehechtheid } & 414\end{array}$

8.5.3 Gehechtheid en gezinshulpverlening 416

8.5.4 Preventie: versterken van sensitief en voorspelbaar opvoeden 417

8.5.5 Bouwen aan veilige gehechtheid: inventariseren 418

8.5.6 Bouwen aan veilige gehechtheid: werken aan gedragsverandering 421

8.5.7 Bouwen aan veilige gehechtheid: hulp aan gezinnen met pubers en adolescenten

8.5.8 Aandacht voor nieuwe gehechtheidsrelaties 425

8.5.9 Adoptie en gehechtheid 427

8.5.10 Inschakelen van aanvullende of specialistische hulp 429

9 Werken aan veiligheid in het gezin 431

$9.1 \quad$ Inleiding 431

9.2 Kindermishandeling, risicofactoren en beschermende factoren 436

9.2.1 Definiëring 436

9.2.2 Gevolgen van kindermishandeling 438

9.2.3 Risicofactoren en beschermende factoren 439

$\begin{array}{lll}9.3 & \text { Partnerschap } & 441\end{array}$

9.3.1 Signs of Safety en de machtsfactor 441

9.3.2 Engageren en positioneren 442

9.3.3 Partnerschap en de aard van de samenwerkingsrelatie 443

$\begin{array}{lll}9.4 & \text { Analyse van de veiligheid } & 447\end{array}$

$\begin{array}{lll}\text { 9.4.1 Drie kernvragen } & 447\end{array}$

$\begin{array}{lll}9.4 .2 & \text { Voorbereiding } & 451\end{array}$

9.4.3 Het belang van het sociale netwerk 452

9.4.4 Eerste kernvraag: waar maken we ons zorgen over? 454

9.4.5 Tweede kernvraag: wat werkt al goed? $\quad 460$

9.4.6 Onderzoek van de omgevingsfactoren 462

9.4.7 Inschatten van de actuele veiligheid in het gezin 463 
9.5 Derde kernvraag: wat moet er gebeuren?

$\begin{array}{lll}\text { 9.5.1 Veiligheidsplan } & 464\end{array}$

9.5.2 Veiligheidsdoelen 465

9.5.3 Werken an werkpunten 468

9.5.4 Evalueren 471

9.5.5 Het proces van veiligheidsplanning: richtlijnen, verfijning en bijstelling $\quad 472$

9.6 In gesprek met kinderen en jongeren 473

9.6.1 De stem van het kind $\quad 473$

9.6.2 Werken aan vertrouwen en partnerschap met een kind 474

9.6.3 De Drie Huizen 476

9.6.4 Het Verhaal in Woord en Beeld 479

9.6.5 Een verhaallijn in woorden en beelden 484

9.6.6 Het Veilige Huis: de bijdrage van het kind aan een veiligheidsplan 487

9.7 Omgaan met ontkenning 493

9.8 Toewerken naar een veiligheidsplan bij gezinshereniging 498

9.9 Reageren op terugval 500

$\begin{array}{lll}9.10 & \text { Bijlagen } & 502\end{array}$

10 Werken aan oplossingen in de omgeving van het gezin 505

10.1 De drie ringen $\quad 505$

10.2 Mobiliseren van sociale steun $\quad 507$

$\begin{array}{lll}10.3 & \text { Versterken van vaardigheden } & 507\end{array}$

10.4 Versterken van bestaande relaties $\quad 510$

10.5 Opbouwen van nieuwe relaties $\quad 512$

10.6 Conflicthantering en bemiddeling 513

10.7 Ondersteunen bij contacten met scholen en instanties 518

10.8 Meegaan naar scholen en instanties $\quad 520$

$\begin{array}{lll}10.9 & \text { Praktische hulp } & 520\end{array}$

11 Reflecteren, monitoren en doelgericht oefenen 523

$\begin{array}{lll}11.1 & \text { Inleiding } & 523\end{array}$

11.2 Implementatie $\quad 525$

11.2.1 Een training ... en dan? $\quad 525$

$\begin{array}{ll}\text { 11.2.2 De fasen van een implementatieproces } & 527\end{array}$

11.2.3 Planmatig implementeren $\quad 530$

$\begin{array}{lll}11.3 & \text { Borging } & 535\end{array}$

11.3.1 Behandelintegriteit $\quad 535$

11.3.2 Doelgericht oefenen $\quad 536$

11.3.3 Het ondersteuningssysteem $\quad 538$

11.4 Ondersteunings- en reflectiebijeenkomsten 539

$\begin{array}{ll}\text { 11.4.1 Training } & 539\end{array}$

11.4.2 Opleiding van startende gezinshulpverleners 541

11.4.3 Teamcoaching en intervisie $\quad 542$

11.4.4 Individuele coaching en consultatie 546

$\begin{array}{ll}\text { 11.4.5 Het parallelproces } & 547\end{array}$ 
11.5 Monitoring van de kwaliteit van gezinshulpverlening

11.5.1 De Check in de cyclus

11.5.2 Instrumenten voor een kwaliteitsmonitor

11.5.3 Het nut van monitoring voor de gezinshulpverlener

11.6 Timemanagement: pak een stoel

11.7 Bijlagen 


\section{Inleiding}

'Een op de tien jongeren krijgt jeugdhulp', kopt NRC Handelsblad op 29 april 2016. Jeugdhulp staat in het huidige tijdsgewricht meer dan ooit in de aandacht van de media. De trend dat het jaarlijkse jeugdzorggebruik toeneemt, hangt hier vermoedelijk mee samen. Bijna 350.000 kinderen en jongeren tussen de 4 en de 18 jaar hebben in 2015 jeugdhulp ontvangen (CBS, 2016). Een indrukwekkend aantal. En dan zijn er veel jeugdigen en hun gezinnen die weliswaar niet dit jaar, maar in de afgelopen jaren van jeugd- en gezinshulp gebruik hebben gemaakt. Het percentage kinderen en jongeren dat ooit in aanraking is geweest met jeugdhulp is daarom veel hoger dan die tien procent van dit jaar. Bedenk daarbij dat de hulp zich in de meeste gevallen richt op de jeugdige én het gezin waartoe hij behoort. Bedenk vervolgens dat naar verhouding veel ouders van deze kinderen uit elkaar zijn en dat in die gevallen er minstens twee gezinnen in aanraking zijn gekomen met jeugdhulp. Deze gezinnen worden omringd door familie, vrienden, buurtbewoners, kennissen, voetbaltrainers, juffen enzovoort. In veel gevallen zullen ook zij, het sociale netwerk, ervan op de hoogte zijn dat een gezin jeugdhulp ontvangt. Vaak vervult het netwerk ook een rol bij de hulp. Kortom: velen komen in een of andere vorm in aanraking met jeugdhulp. Er zijn ook behoorlijk wat jeugdhulpverleners die zelf ook een beroep moeten doen op jeugdhulp. Of die persoonlijk een kind of een gezin kennen die in nood verkeren.

Alleen al statistisch gezien kan dat niet anders.

Een betoog waarom de jeugdzorg groeit voert hier te ver. Het maakt in elk geval de relevantie van goede, effectieve zorg alleen maar groter. Het inzicht dat je een kind of jongere in nood het beste helpt als je als hulpverlener het gezin centraal stelt in het hulpaanbod is inmiddels gebaseerd op wetenschappelijke kennis. Daar waar de opvoedingsnood ontstaat, kan het beste naar oplossingen gezocht worden. De tijd dat we als jeugdhulpverleners de zorg en opvoeding van kinderen van 'falende ouders' overnamen is voorbij. Extreme uitzonderingen daargelaten.

\section{Gezinshulpverlening in ontwikkeling}

In jeugdhulp waarin het gezin centraal staat, zien professionals het gezin als geheel, als hun voornaamste cliëntsysteem. Een goed functionerend gezin is immers de plek waar de voorwaarden geboden kunnen worden om een kind in liefde en veiligheid te laten opgroeien en zich te laten ontwikkelen.

Het gezin centraal stellen wil zeggen dat jeugdprofessionals ernaar streven gezinnen met opgroei- en opvoedproblemen intact te laten en ze te helpen de crises, tegenslagen en schijnbaar uitzichtloze omstandigheden, die de gezonde ontwikkeling van een opgroeiend kind kunnen bedreigen, te overwinnen

In de jeugdhulp stond het gezin lange tijd niet centraal. De kentering naar een gezinsgerichte benadering heeft in het laatste decennium van de twintigste eeuw een vlucht genomen. Bij de eerste druk van dit boek stelden we in de inleiding dat ambulante hulpverlening aan gezinnen in de jeugdzorg al jaren hoog op de agenda staat en dat in de periode daarvoor veel 
varianten van ambulante pedagogische gezinshulpverlening als paddenstoelen uit de grond rezen. Verder concludeerden we dat in de jeugdzorg steeds meer de noodzaak gevoeld werd om evidence-based methoden en hulpvormen te ontwikkelen - die dus aantoonbaar effectief zijn. En dat van instellingen voor jeugdzorg gevraagd wordt de kwaliteit van hun hulp aan te tonen. Deze roep om evidence-based programma's en methoden is ruimschoots beantwoord. In de jaren na het verschijnen van de eerste druk zijn er vele ambulante programma's voor hulp aan jeugd en gezin ontstaan, al dan niet met een evidence-based kwalificatie. Vele daarvan werden geïmporteerd uit andere landen.

De groei en ontwikkeling van het onderzoek naar effecten van jeugdhulp en de trend van de evidence-based hulpverlening, heeft het landschap van de jeugdhulp danig beïnvloed en veranderd. In dit boek gaan we nader in op deze trend en bespreken we hoe het denken over evidence-based hulpverlenen en effectonderzoek zich verder ontwikkelt en wat dat kan betekenen voor het methodisch handelen van gezinshulpverleners.

Gezinsgerichte hulp aan kinderen en jongeren die tijdelijk of permanent niet thuis kunnen verblijven, was in het midden van het eerste decennium van de huidige eeuw meer uitzondering dan regel. Maar ook binnen de jeugdhulp met verblijf is een kentering gaande en staat het gezin waar het kind in de verblijfsvoorziening bij hoort steeds meer centraal. De toegenomen kennis over 'wat werkt' in de jeugdsector heeft bijgedragen aan deze ontwikkeling. Kortom, we kunnen nog steeds stellen dat jeugd- en gezinshulpverlening permanent in ontwikkeling is en vermoedelijk zullen we deze stelling in de toekomst kunnen handhaven. Er zijn daarom ook vele boeiende en zinvolle methodiekbeschrijvingen en boeken op dit terrein. En op internet zijn diverse richtlijnen, handleidingen en 'toolkits' te vinden voor effectieve gezinshulpverlening aan allerlei doelgroepen.

\section{Relevantie}

Wat is dan de relevantie van een handboek als Het gezin centraal als er zo veel kennis en informatie beschikbaar is?

Het boek dat je nu in je handen hebt, is in diverse opzichten onderscheidend. In dit handboek presenteren we een niet-geprotocolleerde, maar wel principiële vorm van gezinshulpverlening: de methodiek Gezin Centraal. Deze methodiek is zowel gezinsgericht (niet het individu, maar het gezin is subject van de hulp) als vraaggericht (de participerende cliënt staat centraal in de hulp). De gezins- en vraaggerichte oriëntering en de oplossingsgerichte benadering zijn in al hun consequenties doorgevoerd in de concrete beschrijving van de gefaseerde hulp, de technieken en vaardigheden van de hulpverlener en de wijze waarop de samenwerkingsrelatie met gezinnen wordt vormgegeven. Voor alle opeenvolgende fasen in de hulpverlening geven we technieken, methoden, stappenplannen en tips, ondersteund door uitgebreid beschreven praktijkvoorbeelden. Deze methodiek is niet abstract of alleen intentioneel beschreven, maar concreet toepasbaar in de dagelijkse praktijk van de hulpverlening aan gezinnen.

De Gezin Centraal-methodiek is ontwikkeld in de dagelijkse praktijk van de afdeling Intensieve Gezinshulpverlening van Cardea Jeugdzorg ${ }^{1}$ te Leiden. Vervolgens is de werkwijze doorontwikkeld in samenwerking met professionals en instellingen in Nederland en Bel-

1 Cardea is een instelling voor jeugdhulpverlening in Leiden en omgeving. Cardea biedt ambulante hulp, daghulp en residentiële hulp aan kinderen van 0 tot en met 18 jaar en hun ouders. 
gië die Gezin Centraal geadopteerd en geïmplementeerd hebben. Met het schrijven van dit handboek worden de inspanningen, de ervaringen en de professionaliteit van degenen die werken met gezinnen en het gezin als de focus van de hulp een warm hart toedragen, vastgelegd en van een kader voorzien.

Het gezin centraal is echter niet het handboek van een exclusief hulpprogramma voor ambulante gezinshulpverlening. De overgrote meerderheid van de ingrediënten in dit boek is relevant voor alle toepassingen van gezinshulpverlening in de jeugdhulp. Als jeugdprofessional, al dan niet in opleiding, zul je bekend zijn met vraaggerichtheid, de systeembenadering, het competentiemodel en de methodiek die de grootste inspiratiebron voor Gezin Centraal vormt: de oplossingsgerichte benadering. De kans is groot dat je deze begrippen niet alleen kent, maar dat ze ook de uitgangspunten vormen van je werk. We hebben getracht alle belangrijke elementen van de werkwijze van gezinshulpverleners weer te geven in een gestructureerd en geïntegreerd geheel.

De methodiek Gezin Centraal verbindt elementen en inzichten uit verschillende methodieken en methodische stromingen met een duidelijke, richtinggevende visie. De essentie van deze visie is dat in de hulpverlening de vragen, behoeften en mogelijkheden van de cliënt centraal staan. Gezinsleden worden gestimuleerd de touwtjes van hun leven (weer) in handen te nemen en te houden, doordat zij de regie kunnen voeren over hun eigen veranderingsproces. In plaats van een sturende, bepalende of paternalistische werkwijze, stellen gezinshulpverleners hun professionaliteit ten dienste van de ontwikkeling van de cliënten en daarom zijn ze gericht op samenwerking. Uit deze visie vloeit de basisattitude van de gezinshulpverleners voort die in deze handleiding wordt gepresenteerd als vraag- en gezinsgericht. Deze houding is bepalend voor de wijze waarop methoden en technieken worden toegepast.

Bij de beschrijving van de basisattitude en de technieken en methoden is uiteraard de invloed van de methodische stromingen terug te vinden. $Z_{o}$ is er een nieuw gebouw ontstaan op de fundamenten die anderen hebben gelegd.

\section{Waarom een nieuwe gewijzigde druk?}

De sector van de jeugdhulpverlening is zeer dynamisch. Sinds de publicatie van de eerste druk van Het gezin centraal, in 2006, heeft de jeugdsector zich in rap tempo ontwikkeld. De ontwikkelingen rond effectonderzoek en evidence-based hulpverlenen hebben we reeds aangestipt. Een andere bepalende verandering is de transformatie van het jeugdstelsel door de decentralisatie van de jeugdhulp per 1 januari 2015, ingegeven door de Jeugdwet die vanaf die datum in werking trad. Beide ontwikkelingen hebben de rol, positie en taakopvatting van ambulant gezinshulpverleners sterk beïnvloed en in sommige opzichte ingrijpend veranderd. De dynamiek in de jeugdsector maakt het actualiseren van Het gezin centraal nuttig en noodzakelijk. De genoemde ontwikkelingen zijn van invloed geweest op het opnemen van nieuwe en het aanpassen van reeds bestaande onderdelen van het handboek. Zo is er aandacht besteed aan generalistische jeugdhulp en het werken met multiprobleemgezinnen op basis van een gezinsplan. Hierbij ligt de nadruk op de vraag hoe je concreet in de rol die je als professional vervult bijdraagt aan de regie, zelfsturing en eigen kracht van de gezinnen. Ook wordt de breedte van de doelgroep en daarmee het werkgebied van ambulante gezinshulpverleners, van kortdurend preventieve opvoedingsondersteuning tot intensieve specialistische gezinsbehandeling al of niet in combinatie met verblijf, uitgebreid behandeld. 
Daarnaast is de werkwijze van de Gezin Centraal-methodiek in de afgelopen 10 jaar ook doorontwikkeld, geïnspireerd door de professionals die dagelijks met de methodiek werken. Zo zijn het werken aan veiligheid en het versterken van het sociale netwerk voorbeelden van elementen die in de gewijzigde druk methodisch verder zijn uitgewerkt en sterker over het voetlicht worden gebracht. Er zijn ook nieuwe methodische elementen om te werken aan concrete, aantoonbare en duurzame gedragsverbetering toegevoegd, zoals de 'methode van de drie gebeurtenissen' waarbij je het dagelijkse gezinsleven benut als werkmateriaal om aan concrete gedragsverandering te werken.

\section{Decentralisatie en een nieuw jeugdstelsel}

De bedoeling van de overheid met de Jeugdwet en de decentralisatie is vereenvoudiging van het stelsel. Jeugdigen, ouders en gezinnen moeten sneller en gemakkelijker bij hulpverleners terechtkunnen met hun opgroei- en opvoedingsvragen (ministerie van VWS \& ministerie van V\&J, 2011).

Tegelijk werd herziening van het jeugdstelsel noodzakelijk geacht om de groeiende vraag en de daarmee gepaard gaande kosten terug te dringen (Van Yperen et al., 2013). Het gewone opvoeden en opgroeien moet worden versterkt om het beroep op specialistische zorg terug te dringen. Daarom zijn de gemeenten nu verantwoordelijk voor het aanbieden van jeugdhulp. De klassieke verzorgingsstaat moet plaatsmaken voor een participatiesamenleving, zei koning Willem-Alexander in de Troonrede van 2013. Deze uitspraak markeert de transformatie die zowel in de samenleving als in de zorgsector geleidelijk gestalte krijgt. De goed georganiseerde verzorgingsstaat heeft in Nederland geleid tot afnemende verantwoordelijkheid van de individuele burger, is de achterliggende opvatting (Denktank Transformatie Jeugdstelsel, 2014). De burger is eraan gewend geraakt dat de overheid en het maatschappelijk middenveld voor elk probleem de burger van professionele hulp en voorzieningen voorzien. Met deze transformatie worden burgers aangesproken op hun gevoel van verantwoordelijkheid. In het nieuwe jeugdstelsel wordt daarom een sterker appèl gedaan op de inzet, de oplossende vermogens en krachten van ouders, opvoeders en jeugdhulpcliënten en hun sociale omgeving. Hiermee is de positie van cliënten veranderd. De kracht en de beschermende factoren in de samenleving, en in het bijzonder in het sociale netwerk en de woonomgeving van ouders en opvoeders, worden gemobiliseerd om opvoedproblemen te voorkomen of in elk geval tijdig te signaleren, zodat er zo snel mogelijk hulp op maat geboden kan worden.

$Z_{o}$ is er een jeugdstelsel ontstaan met vier categorieën (of niveaus) van voorzieningen die bijdragen aan de bedoeling van de overheid om het recht van kinderen en jongeren om veilig, gezond op te groeien en hun talenten te ontwikkelen, zo veel mogelijk te waarborgen (Metselaar, 2016).

Het jeugdstelsel telt de volgende vier categorieën:

1 Pedagogische gemeenschap

2 Gemeentelijke basisvoorzieningen

3 Vrij toegankelijke jeugdhulp, vaak in gebiedsgerichte teams

4 Specialistische hulp (zoals jeugd-ggz, hulp aan LVB-jeugd en hun gezinnen, jeugdzorg met verblijf) 
De integrale aanpak van jeugdhulp op basis van de uitgangspunten van 1Gezin1Plan, moet de samenhang tussen de niveaus waarborgen.

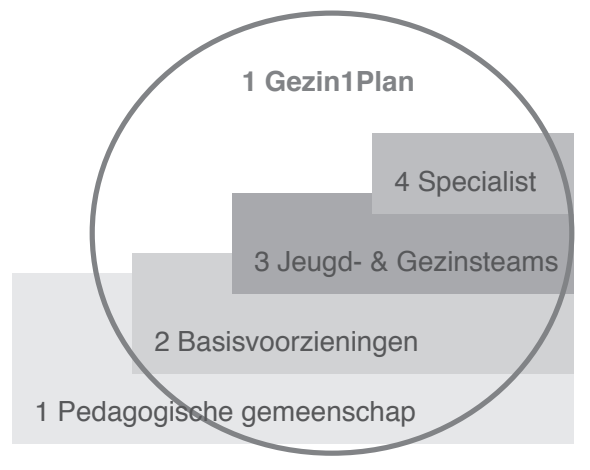

De pedagogische gemeenschap, ook wel de pedagogische civil society genoemd, vormt het fundament van het stelsel. In een goed functionerende pedagogische gemeenschap zijn burgers betrokken en bereid om in hun eigen sociale netwerk en in het publieke domein verantwoordelijkheid rond het opgroeien en opvoeden van kinderen te nemen (Kesselring et al., 2013). Een pedagogische gemeenschap wordt gevormd door ouders, kinderen/jongeren en buurtbewoners, maar ook door familieleden, leraren, geloofsgemeenschappen, sportcoaches en lokale ondernemers. Gemeenten vervullen in het nieuwe jeugdstelsel een stimulerende rol bij het versterken van de pedagogische gemeenschap.

De tweede categorie in het jeugdstelsel wordt gevormd door de basisvoorzieningen: de voorzieningen waar vrijwel alle ouders en kinderen komen. Denk daarbij aan de jeugdgezondheidszorg, kraamzorg, peuterspeelzalen, scholen, jongerenwerk, welzijnswerk, kinderopvang, huisartsen en andere voorzieningen in de gezondheidszorg. In het nieuwe jeugdstelsel wordt van deze voorzieningen gevraagd dat zij expliciet en actief bijdragen aan de doelstellingen van de overheid met betrekking tot de gezonde ontwikkeling van kinderen en daarnaast aan actief burgerschap en participatie (Metselaar, 2016). Het versterken van de eigen kracht en het stimuleren van sociale netwerken maken onderdeel uit van de ondersteunende taak van deze voorzieningen.

De derde categorie bestaat uit voorzieningen voor de gemeentelijke, vrij toegankelijke, laagdrempelige jeugdhulp. Deze gemeentelijke 'eerstelijns'-jeugdhulp is opgericht om een cruciale rol te vervullen bij het vereenvoudigen en ontkokeren van het stelsel en de vermindering van het gebruik van specialistische voorzieningen. De eerstelijnsvoorzieningen hebben een scharnierfunctie in het stelsel (Denktank Transformatie Jeugdstelsel, 2014).

Deze voorzieningen dragen bij aan de intentie van de overheid om meer nadruk te leggen op preventie. Als gezinnen in een vroeg stadium met opgroei- en opvoedproblemen terechtkunnen bij laagdrempelige jeugdhulp en opvoedingsondersteuning, dan kan eerstelijnshulpverlening het gezin stimuleren om oplossingen in het gewone leven (familie, sociaal netwerk, buurt, school, basisvoorzieningen) te vinden. Zo kan worden voorkomen dat jeugdhulp pas ingeschakeld wordt als de relatief lichte gezinsproblemen uitgegroeid zijn tot ernstige en ontwrichtende problemen. De eerstelijnsprofessional voorkomt escalatie van opgroei- en op- 
voedproblemen en onnodige medicalisering, biedt zelf jeugd- en gezinshulpverlening, maar doet ook, waar nodig en tijdig, een beroep op specialistische zorg.

In veel regio's en gemeenten krijgt deze vrij toegankelijke jeugdhulp gestalte in buurt-, wijkof Jeugd- en Gezinsteams. Deze teams jeugdprofessionals werken gebiedsgericht in deelgemeenten, wijken of dorpen en hebben daar ook hun werkplek: vaak in of dicht bij basisvoorzieningen als scholen, Centra voor Jeugd en Gezin en gezondheidscentra.

De Jeugd- en Gezinsteams hebben een brede taakstelling en expertise op het gebied van de meest voorkomende opvoed- en opgroeiproblemen.

Professionals in deze teams worden vaak aangeduid als jeugdgeneralisten. In dit boek gaan we ook nader in op de rol, taak en werkwijze van deze professionals.

De vierde categorie komt aan bod als de hulp in de Jeugd- en Gezinsteams niet toereikend is. Dan worden voorzieningen voor specialistische jeugdhulp ingeschakeld. Denk bijvoorbeeld aan de jeugd-ggz of jeugdpsychiatrie, verslavingszorg, specialistische hulp aan gezinnen, ouders en jeugdigen die te maken hebben met een lichte verstandelijke beperking of intensieve vormen van jeugdzorg, bijvoorbeeld residentiële verblijfsvoorzieningen en pleegzorg. De jeugdreclassering en de jeugdbescherming vallen ook onder deze categorie.

De onderverdeling in categorieën kan een statische indruk maken. Alsof er een categorie gekozen moet worden als er zorg of ondersteuning aan gezinnen aan de orde is. Het stelsel is echter niet bedoeld als een doorschuifsysteem van de ene naar de andere categorie. De bedoeling is dat er samenhang en samenwerking tussen de verschillende categorieën ontstaat. De structuur van het jeugdstelsel moet worden opgevat als een zorgcontinuüm, waarin zo nodig professionals uit verschillende categorieën uitgenodigd worden om met het gezin en zijn netwerk samen te werken aan de oplossing van hun vragen en problemen (Metselaar, 2016).

Daarmee komen we terecht bij de integrale jeugdhulp volgens $1 \mathrm{Gezin} 1 \mathrm{Plan}$. Dat is een werkwijze en een manier van organiseren van hulp die de samenhang en de continuiteit van de zorg en hulp aan gezinnen moeten waarborgen (Bolt \& Van der Zijden, 2014). Een samenwerkingsverband van professionals en instanties rond gezinnen in nood biedt integrale zorg in nauwe samenwerking met het gezin en zijn sociale netwerk. Hierbij gaat het niet alleen om samenhang van de jeugdhulp, maar ook om verbinding met andere domeinen. Een gezin dat met opvoedingsproblemen én met schulden én met huisvestingszorgen kampt, is erbij gebaat dat de jeugd- en gezinshulpverleners met wie ze te maken hebben niet alleen met hen, maar ook met bijvoorbeeld de schuldhulpverlener en een functionaris van de woningbouwvereniging nauw samenwerken. Met elkaar, het gezin, zijn netwerk en de betrokken professionals, werken ze samen aan één gezinsplan, het plan waarvan het gezin zelf de eigenaar is. En met elkaar zijn de instanties en professionals verantwoordelijk voor het versterken van de eigen kracht en het oplossend vermogen van het gezin. Het feit dat voorzieningen op meerdere domeinen onder de verantwoordelijkheid van de gemeente vallen, zou de samenwerking en de samenhang moeten bevorderen.

In het nieuwe stelsel functioneren ambulant gezinshulpverleners geregeld als spil in de samenwerking tussen de verschillende categorieën en in de samenwerking rond een gezin volgens 1 Gezin1Plan. 


\section{De kern}

Hoewel de decentralisatie en het nieuwe jeugdstelsel veel teweeggebracht hebben in het vak van de ambulant gezinshulpverlener, is de kern zoals we die in Het gezin centraal presenteren overeind gebleven. Het bevorderen van 'eigen kracht' en empowerment is nog steeds de hoofddoelstelling. Het bevorderen van het oplossend vermogen met behulp van de oplossingsgerichte benadering past als een jas bij de transformatie van de jeugdhulp. Het bezien van het gezin in zijn maatschappelijke context is onderdeel van de systeemtheoretische kijk op hulp van gezinshulpverleners.

De decentralisatie en de transformatie hebben het vak niet zozeer wezenlijk veranderd, maar van nieuwe dimensies voorzien. Dit heeft geleid tot een aantal essentiële en noodzakelijke aanpassingen en aanvullingen op het oude handboek in de beschrijving van en toelichting op de attitude en werkwijze van de ambulant gezinshulpverlener.

Welke veranderingen de jeugdhulp ook ondergaat, de vraag naar in hoeverre jeugdhulp daadwerkelijke helpt, dus wezenlijke veranderingen voor gezinnen teweegbrengt, is altijd relevant. In deze herziene druk gaan we uitgebreid in op de vraag: wat kun je als jeugd- en gezinshulpverlener doen om je persoonlijke effectiviteit aantoonbaar te vergroten? Een methode is immers zo goed als degene die hem uitvoert. We gaan daarom uitgebreid in op zaken als het monitoren van kwaliteit. Het gaat daarbij om effectonderzoek, behandelintegriteit en methodische reflectie. Een effectieve hulpverlener is zelfbewust en daarom voortdurend gericht op het ontvangen van feedback.

Als je als gezinshulpverlener zelfsturing en zelfbewustzijn bij jezelf weet te bevorderen, dan helpt dat je hetzelfde te bewerkstelligen bij de gezinnen die je dagelijks ontmoet.

\section{Doelen}

Met dit handboek beogen we een aantal doelen.

1 Het geven van praktische richtlijnen en structuur aan het werk van ambulant gezinshulpverleners en andere professionals die te maken hebben met het adviseren, ondersteunen en begeleiden van gezinnen. Daarom zijn de beschrijvingen van theorie, attitude, methoden en technieken concreet en geillustreerd met veel voorbeelden uit de praktijk. Het is daardoor geen boek geworden om per se van kaft tot kaft te lezen - al bevelen we dat natuurlijk wel aan. De lezer kan de passages kiezen die op dat moment relevant zijn voor zijn werk. Wel is het van belang dat alle elementen met elkaar samenhangen en dat de centrale visie, gebaseerd op vraaggerichtheid, de oplossingsgerichte benadering en de systeembenadering, hierin het bindmiddel vormt.

2 We beschrijven niet alleen de technieken en methoden, maar ook en vooral het proces van de gezinshulpverlening en de wijze waarop een gezinshulpverlener een samenwerkingsrelatie met zijn cliënt opbouwt, onderhoudt en benut.

3 Het boek is bedoeld als een bruikbaar leermiddel bij de training, opleiding en coaching van (beginnende) gezinshulpverleners.

4 De inhoud van het handboek biedt een belangrijke basis voor wetenschappelijk onderzoek op het gebied van proces en effect van hulpverlening aan gezinnen.

5 Het boek is bedoeld om professionals te inspireren bij de uitoefening van hun vak en om hun liefde en enthousiasme voor het werken met gezinnen aan te wakkeren. Als het een 
kleine bijdrage kan leveren aan het plezier van de lezer in zijn werk en aan de waardering voor de gezinnen die hij ontmoet, dan is dit doel ruimschoots behaald. 


\section{Gezinshulpverlening: doelgroep, doelen en varianten}

\section{$1.1 \quad$ Inleiding}

Opvoeden gebeurt grotendeels thuis. Als er problemen zijn bij het opvoeden, merk je dat thuis het eerst. Ambulante gezinshulpverlening is een systeemgerichte vorm van jeugdhulp die hulp biedt bij het opvoeden in de dagelijkse woonomgeving van gezinnen. Waar de problemen ontstaan, zijn tevens de oplossingen te vinden. Juist om die oplossingen te ontdekken, is het belangrijk dat de hulpverlening plaatsvindt op de bank of aan de keukentafel bij de gezinnen thuis. De hulp richt zich niet uitsluitend op het kind of de jongere, maar op het gehele gezin of de gehele familie.

De hulp is bedoeld voor gezinnen met milde tot ernstige opgroei- en opvoedproblemen. Deze gezinnen vragen hulp omdat de balans tussen draaglast en draagkracht verstoord is geraakt, waardoor de gezonde ontwikkeling en het welzijn van de jeugdige benadeeld of bedreigd wordt.

De gezinshulpverlening is ambulant omdat de hulp grotendeels bij de gezinnen thuis plaatsvindt. Kenmerkend voor de werkwijze van de gezinshulpverlener is dat het gezinsleven het uitgangspunt en het oefenterrein vormt. Frequentie, intensiteit en duur worden afgestemd op de hulpvraag en de voortgang van de begeleiding.

Nog even iets over de term 'ambulant'. 'Ambulant' betekent: niet gebonden aan een vaste plaats. In Vlaanderen wordt onderscheid gemaakt tussen 'mobiele' en 'ambulante' hulp. Mobiele hulp wordt daar verleend door een hulpverlener die op pad gaat, letterlijk mobiel is en de cliënten thuis opzoekt. De hulpverlener is niet alleen niet gebonden aan een vaste plaats, maar is voortdurend in beweging en flexibel, dus mobiel. Zorgvuldig geformuleerd.

Onze zuiderburen reserveren de term 'ambulant' voor hulpvormen waarbij de cliënt de hulpverlener opzoekt voor hulpverleningsgesprekken.

In Nederland gebruiken we 'ambulant' voor beide vormen van hulp. Veel gezinshulpverleners bezoeken de gezinnen vooral thuis, maar wisselen dat af met afspraken 'op kantoor'.

Er zijn veel gezinnen in Nederland die gebruikmaken van gezinshulpverlening in een of andere vorm. Het aantal kinderen en jongeren met serieuze opgroei- en opvoedproblemen wordt geschat op ongeveer 15\%, waarbij voor $5 \%$ geldt dat de problemen ernstig en structureel zijn (Van Dorsselaer et al., 2010; Van Zeyl et al., 2005).

In 2015 ontving zo'n 8\%, bijna 350.000 jeugdigen en hun gezin, jeugdhulp (CBS, 2016). Het merendeel van deze gezinnen wordt begeleid door ambulant gezinshulpverleners, al of niet in samenwerking met andere voorzieningen als pleeg- of residentiële zorg. 